\title{
Chargeable in Court vs. Insanity-Mental Illness
}

\author{
*Nuno Nogueira \\ Forensic Clinical Assessment, Instituto Cognos, Portugal
}

Submission: February 23, 2017; Published: March 06, 2017

*Corresponding author: Nuno Nogueira, Forensic Clinical Assessment, Instituto Cognos, Porto, Rua Garcia Domingues, №12, R/c Dto, 8100-231 Loulé, Portugal, Europe, Tel:+351 967263 202; Email: denogueira.nuno@gmail.com

\section{Perspective}

A person can be considered chargeable (responsible for a crime) in the court if proved having a Psychopathic personality. This means that the individual doesn't suffer from a mental illness and so, thus not qualifying it for the category of non chargeable or insanity. The insanity category includes the mental illnesses, summarized in the DSM-IV, in which the person is not aware of the acts committed at the time of the crime, so he can't be blamed by the court for the acts committed. Psychopathy as mentioned, not being a mental illness, invokes that the accused is fully aware of the acts he has committed in a specific time, or even years, and nevertheless he decides to commit them repeatedly, regardless of the consequences that may result when he is captured, like the eminent incarceration of life time, death penalty by lethal injection (in the majority of US stated), by hanging (e.g. Delaware), electric chair, gas chambers like Wyoming or even by firing (squadron platoon) in Oklahoma and Utah, this last one, only if request by the criminal person, being the last death by firing in 2010. In general terms, Psychopathy is considered to be a personality disorder (not mental illness), in which the individual is fully aware of the malicious acts his practicing and their consequences in the case of being discovered [1].

These individuals do not distinguish "love" from "horror", or at the least, they understand it in a way that is very superficial and distant. They are oblivious to the suffering of others, as if there was an emotional apathy, detachment, and a severe lack of attachment and connection to other people. The most recent studies indicate that psychopathy is related to a breakdown in socialization, possibly due to a gap in the temperament of each individual, to various situations of abuse and neglect (parental), or even by close influence of other individuals. Certain phenotypes were elaborated with regard to the psychopathy: boldness that is determined by audacity and daring, in wanting achievement; evilness, in the concept of doing the wrong thing, knowing that is bad and evil, and the pettiness associated with not thinking about other persons or in the suffering that may be caused to them; Disinhibition related to the control of the individual impulses [2].

These factors are closely linked to the externalization of deviance and lack of emotional attachment to others, detachment, and the issues of deception and the concept of lying. In contemporary conceptions this personality (psychopathic) was considered to have characteristics such as emotional coldness, impulsiveness, explosiveness (resulting from any frustrating act - aggression) and irresponsible, these being the most current characteristics on which the profilers were based. Other characteristics have emerged over the years, as are paradigmatic examples of charm, persuasion and affability with others, which clearly masks the essence of the person, which is in fact a human being integrated into a community with atypical personality, thus being able to insert himself well in his profession and with colleagues through a highly calculating and treacherous spirit, capable of manipulation to reach its ends $[3,4]$. Serial killers have a characteristic modus operandi and something of their own, including here the desecration of a corpse, mutilation, and can save parts of the body as "trophies", in some cases.

Even in the face of hideous, brutal and murderer scenarios, psychopaths retain their mental faculties intact, having the ability to discern and self-determine their acts, their own mental judgment as a person, acting in a thoughtful way, manipulative and cold, seeing others like objects that can be used, hurt, manipulated and discard in the same way, including death, not seeing them as equal to himself or belonging to the same world of his. When the degree of this insensitivity is high, with a marked affective indifference, it can adopt recurrent criminal behavior and the clinical picture of personality disorder takes on the form called psychopathy. Personality disorders are one of the main and most update problems of current forensic psychology. Psychopathy is the most serious personality disorder, presenting a greater number of crimes and more serious from the legal point of view, very violent, recorded in the history of humanity, 
still presenting a high rate and high levels of recidivism. Serial killers, if not discovered by the authorities, can hardly stop their criminal behavior, sometimes even leaving clues for the police to find, a sort of a challenge or game, to incite the police to try to capture them. Some of well-known psychopaths of recent decades includes Pedro Alonso Lopez, Dr. Jack Kevorkian or Anders Breivik in 2011 in Norway that killed 77 persons and led to a 21 years in prison [5-7].

\section{References}

1. American Psychiatric Association (2000) D.S.M-IV-TR, Manual de Diagnóstico e Estatística da Perturbações Mentais ( $4^{\text {th }}$ edn). Lisboa: Climepsi Editores.
2. Barker R (1968) Ecological Psychology: concepts and methods for studying the enviroment of human behavior. Stanford University Press, USA.

3. Cleckley Hervey (1976) The Mask of Sanity. Mosby Co, USA.

4. Cordeiro JD (2003) Psiquiatria Forense. Lisboa: Fundação Calouste Gulbenkian.

5. Debuyst C (1977) Le concept de dangerosité et un de ses éléments constitutifs: la personnalité (criminelle). Déviance et Société 1(4): 363-388.

6. Dias F, Andrade C (1997) Criminologia: o homem delinquente e a sociedade criminógena. Coimbra: Coimbra Editora.

7. Hare R (1993) Without Conscience: The Disturbing World of the Psychopaths among us. Guilford Press, USA.

\section{Your next submission with Juniper Publishers} will reach you the below assets

- Quality Editorial service

- Swift Peer Review

- Reprints availability

- E-prints Service

- Manuscript Podcast for convenient understanding

- Global attainment for your research

- Manuscript accessibility in different formats

(Pdf, E-pub, Full Text, Audio)

- Unceasing customer service

Track the below URL for one-step submission https://juniperpublishers.com/online-submission.php 